\title{
Trophinin and tastin, a novel cell adhesion molecule complex with potential involvement in embryo implantation
}

\author{
Michiko N. Fukuda, ${ }^{1,4}$ Takaaki Sato, ${ }^{1}$ Jun Nakayama, ${ }^{1}$ George Klier, ${ }^{1,3}$ Mikio Mikami, ${ }^{1,2}$ \\ Daisuke Aoki, ${ }^{2}$ and Shiro Nozawa ${ }^{2}$ \\ ${ }^{1}$ La Jolla Cancer Research Foundation, La Jolla, California 92037 USA; ${ }^{2}$ Department of Gynecology and Obstetrics, \\ Keio University School of Medicine, Tokyo, Japan
}

\begin{abstract}
Two human epithelial cell lines, trophoblastic teratocarcinoma HT-H and endometrial adenocarcinoma SNG-M cells, adhere to each other at their respective apical cell surfaces in a divalent cation-independent manner. Two novel molecules responsible for the adhesion between these two cell types were identified by expression cDNA cloning. One, named trophinin, is an intrinsic membrane protein and mediates homophilic self-binding. Another, named tastin, is a cytoplasmic protein and is necessary for trophinin to function as a cell adhesion molecule. Trophinin and tastin appear to be associated with the cytoskeleton in HT-H and SNG-M cells. These molecules are normally not expressed in various types of human cells in tissues, with the exception of macrophages. Strong expression of these molecules was detected in the trophectoderm surface of monkey blastocyst. These molecules are also expressed in human endometrial surface epithelium on day $16 / 17$ at the early secretory phase of human endometrium, the time consistent with that expected for the "implantation window."
\end{abstract}

[Key Words: Trophoblast; polarized epithelium; cytoskeleton; molecular cloning; embryo]

Received February 14, 1995; revised version accepted March 30, 1995.

Although the precise morphological events of implantation vary from species to species, one essential feature is the formation of allogeneic and heterotypic cell-to-cell contacts between embryonic and maternal cells. The early events of implantation are an initial apposition of the trophoblast to the uterus and subsequent adhesion of the trophoblast to the endometrial epithelium (Sclafke and Enders 1975; Enders et al. 1981; Kaufman 1985; Ringler and Strauss 1990; Aplin 1991). The initial attachment of the trophoblast to the endometrial epithelium is unusual in that this cell-to-cell contact occurs via their respective apical cell membranes. In general, the apical surface of the epithelium is not adhesive, whereas the basolateral surface supports adhesion. One hypothesis is that the apical surfaces of the trophectoderm and uterine epithelium express a "basolateral" character that promotes adhesion between the blastocyst and the uterine epithelium (Leivo et al. 1980; Armant et al. 1986; Farach et al. 1987; Sutherland et al. 1988). Alternatively, the apical plasma membranes of the trophoblast and endometrial epithelia express unique cell adhesion molecules that mediate an initial attachment between these cells (Kliman et al. 1989).

\footnotetext{
${ }^{3}$ Present address: Department of Cell Biology, Scripps Research Institute, La Jolla, California 92037 USA.

${ }^{4}$ Corresponding author.
}

Attempts to identify molecules involved in embryo implantation have been conducted both in vivo and in vitro (Leivo et al. 1980; Armant et al. 1986; Farach et al. 1987; Kimber et al. 1988; Lindenberg et al. 1988; Sutherland et al. 1988; Romagnano and Babiartz 1990; Yamagata and Yamazaki 1991). Analysis of implantation at the molecular level, however, has been difficult because of the lack of tractable model systems, particularly if the human embryo is the subject to be analyzed.

In vivo, human endometrium is under strict hormonal controls and is generally not permissive to implantation (Yoshinaga 1988). During a relatively short time in the menstrual cycle, the surface epithelium of the endometrium becomes receptive to trophoblast attachment (Harper 1992). It is difficult to reproduce such an "implantation window" using endometrial epithelia in tissue culture. However, recent studies using several endometrial adenocarcinoma cell lines suggest that some of the adenocarcinoma cells interact with trophoblastic cells at their apical cell surfaces (John et al. 1993; Rohde and Carson 1993).

Morphological studies of human embryo implantation indicate that trophoblasts of the blastocyst that are in contact with the endometrial epithelia are binucleated, suggesting early syncytia formation at the implantation stage (Lindenberg et al. 1986). We have shown previously that HT-H human teratocarcinoma cells (Ducibella et al. 
1982) spontaneously differentiate into syncytiotrophoblast-like cells (Izhar et al. 1986). Because cell lines established from teratocarcinoma tumors often show characteristics of cells at early embryonic stages (Martin 1980; Andrew et al. 1983), HT-H cells were thought to exhibit both embryonic and syncytiotrophoblastic properties.

In this paper we describe the adhesion of HT-H cells (Izhar et al. 1986) to endometrial adenocarcinoma SNG-M cells (Ishiwata et al. 1977) and identify the molecules responsible for the cell adhesion between these two cell types. The expression pattern of the cloned molecules in vivo and activity of the cloned proteins support the possibility that they mediate the adhesion of the blastocyst to the endometrial epithelium at the time of implantation.

\section{Results}

Trophoblastic teratocarcinoma HT-H cells adhere to the upper surface of endometrial adenocarcinoma SNG-M cells

The adhesion of HT-H cells to several human endometrium epithelial cells was examined (Table 1). The HT-H cells attached to the SNG-M, HeclA, KLE, and RL95-2 cells but did not adhere to the AN3CA cells. Because HT-H cells adhere to SNG-M cells most efficiently in the presence of EDTA, adhesion between these two cell lines was analyzed further.

HT-H cells adhered efficiently to the SNG-M cells $(\mathrm{Ta}$ ble 1). SNG-M cells also adhered to their own cell type (Fig. 1A), suggesting that the adhesion between these two cell types is mediated by a homophilic adhesion mechanism rather than ligand receptor-type heterophilic adhesion mechanism. COS-1 cells adhered poorly to a monolayer of SNG-M cells (Fig. 1A). Other types of epithelial cells, HeLa, HepG2, SW480, and A431, did not adhere to monolayers of the SNG-M cells.

Similar results were obtained when HT-H cell monolayers were tested for adhesion (not shown), indicating that adhesion between the HT-H and SNG-M cells is homophilic and cell type-specific and occurs at their respective upper cell surfaces.

\section{Morphological characterization of HT-H and SNG-M cells at contact}

Attachment of HT-H and SNG-M cells was examined under an electron microscope. At $10 \mathrm{~min}$ after contact, HT-H cells were seen with their upper surfaces facing the upper surface of SNG-M cells (Fig. 2A,B). There are many microvilli between these two cell types. Electron microscopy of the cells after $6 \mathrm{hr}$ of coculture shows closer adhesive interactions between these two cell types (Fig. 2C). After 4 days of coculture, the microvilli disappeared completely from the surfaces of both cell types and desmosome-like adherent junctions were formed between the HT-H and SNG-M cells (Fig. 2D).

Morphological studies of human embryo implantation
Table 1. Adhesion of HT-H cells on the upper surfaces of endometrial adenocarcinoma cells

\begin{tabular}{|c|c|c|}
\hline \multirow{2}{*}{$\begin{array}{l}\text { Endometrial } \\
\text { adenocarcinoma } \\
\text { cells }^{\mathrm{a}}\end{array}$} & \multicolumn{2}{|c|}{$\begin{array}{l}\text { HT-H cells attached } \\
|\%|\end{array}$} \\
\hline & EDTA $^{-}$ & $\mathrm{EDTA}^{+}$ \\
\hline SNG-M & $56.9 \pm 8.2$ & $49.7 \pm 7.3$ \\
\hline HeclA & $29.6 \pm 10.2$ & $24.2 \pm 8.3$ \\
\hline KLE & $32.5 \pm 8.5$ & $27.3 \pm 4.8$ \\
\hline RL95-1 & $83.5 \pm 9.7$ & $20.4 \pm 12.1$ \\
\hline AN3CA & $4.2 \pm 0.8$ & $2.1 \pm 0.6$ \\
\hline
\end{tabular}

${ }^{a} \mathrm{All}$ assays were performed by using live ${ }^{35} \mathrm{~S}$-labeled HT-H cells suspended in HBS $\{10 \mathrm{mM}$ HEPES buffer at $\mathrm{pH} 7.4$ containing $0.12 \mathrm{M} \mathrm{NaCl}$ ). Twenty minutes after adding HT-H cells on the monolayers, nonadherent HT-H cells were washed with HBS with or without $1 \mathrm{mM}$ EDTA. Numbers are expressed as percent radioactivity remaining on the monolayer relative to the total radioactivity of ${ }^{35} \mathrm{~S}$-labeled HT-H cells added. The results were obtained by each triplicate experiment.

${ }^{b}$ Unfixed monolayers of endometrial adenocarcinoma cells were used in these adhesion assays. Trophoblastic HT-H cells were separated from undifferentiated HT-H cells as described, subcloned, and used in the present study. Endometrial adenocarcinoma cell lines HeclA, RL95-2, and AN3CA were obtained from the American Tissue Culture Collection. All cell lines were cultured in DMEM containing $10 \%$ fetal bovine serum, 2 $\mathrm{mm}$ glutamine, $100 \mathrm{U} / \mathrm{ml}$ of penicillin, and $100 \mu \mathrm{g} / \mathrm{ml}$ of streptomycin. HT-H cells were metabolically labeled with $T$ ran ${ }^{35} S-$ label (New England Nuclear) in methionine- and cysteine-free RPMI medium for $20 \mathrm{~min}$ and chased with complete medium for $2 \mathrm{hr}$. The ${ }^{35} \mathrm{~S}$-labeled HT-H cells were detached from the bottom of the tissue culture dishes using cell dissociation solution (Specialty Media, Lavalette, N]). The cells $\{0.2 \mathrm{ml}, 5 \times$ $10^{5}$ cells) were suspended in HBS and added to the monolayers of endometrial adenocarcinoma cells that had been grown on the bottom of a 24-well tissue culture plate. After $20 \mathrm{~min}$, the monolayers were washed three times with HBS with or without $1 \mathrm{mM}$ EDTA. The cells remaining in each well were solubilized with $0.5 \mathrm{ml}$ of $0.5 \mathrm{~N} \mathrm{NaOH}$ and $1 \%$ SDS, and radioactivity was counted.

in vivo (Knoth and Larsen 1972) and in vitro (Lindenberg et al. 1986/demonstrate similar characteristics shown in Figure 2, except that the trophoblasts intrude between endometrial epithelia in vivo and HT-H cells do not intrude between SNG-M cells.

\section{Expression cloning of molecules mediating adhesion} between HT-H and SNG-M cells

As COS-1 cells do not adhere to a monolayer of SNG-M cells (Fig. 1A), it was expected that if COS-1 cells were transfected by cDNAs encoding an appropriate adhesion molecule, they would acquire the ability to adhere to a SNG-M cell monolayer.

A cDNA library of the HT-H cells was constructed in the mammalian expression vector pcDNAI, and COS-1 cells were transfected with the library. After two rounds of screening (see Materials and methods for details), 

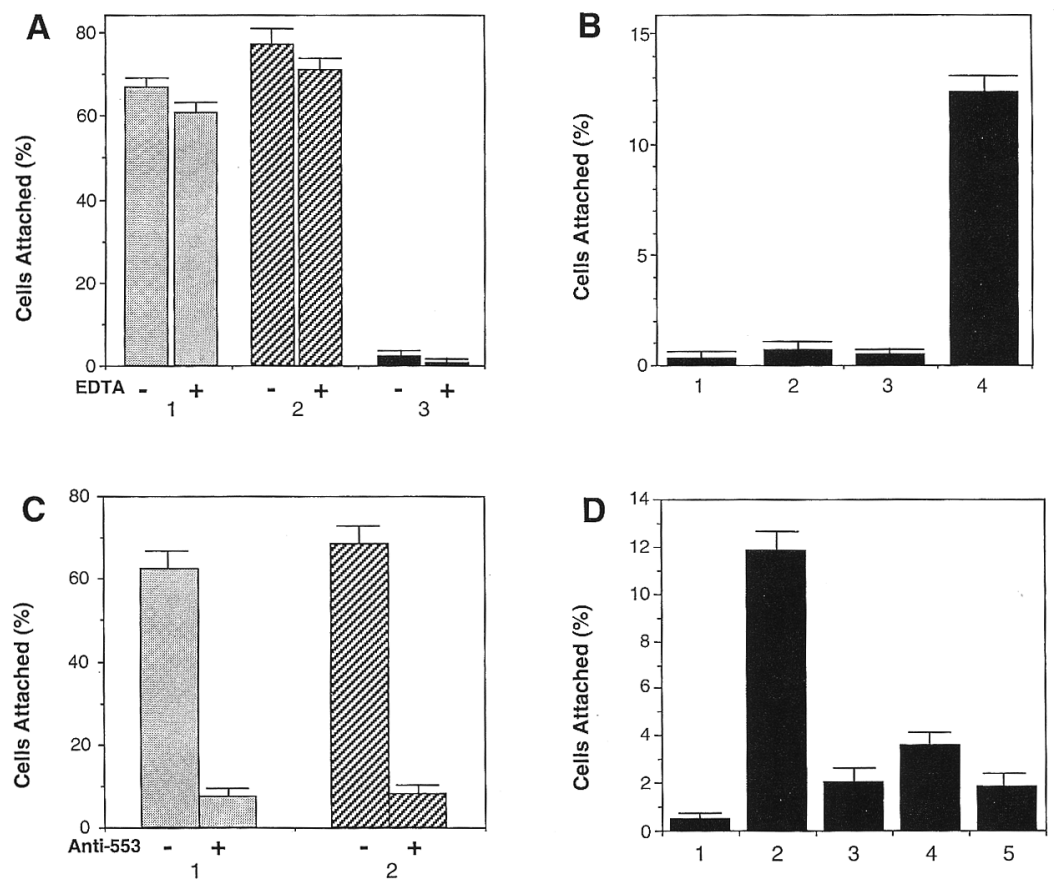

Figure 1. Binding of $\mathrm{HT}-\mathrm{H}$, SNG-M, and COS-1 cells to monolayers of SNG-M cells or transfected COS- 1 cells. Adhesion assays were conducted as shown in Table 1, except that monolayers were prefixed with $1 \%$ paraformaldehyde at room temperature for $15 \mathrm{~min}$. Numbers presented are the averages obtained by triplicate experiments. $|A|$ Binding of HT-H (1), SNG-M (2), and COS-1 (3) cells to monolayers of SNG-M cells. (B) Adhesion of COS-1 cells to monolayers of SNG-M cells. COS- 1 cells were transfected with pcDNAI vector alone (1), tastin cDNA alone (2), trophinin cDNA alone (3), or a mixture of tastin and trophinin cDNAs (4). (C) Effect of anti-trophinin antibodies on cell adhesion. Each monolayer of the SNG-M cells was pretreated either with anti-trophinin (GST553) antiserum or with preimmune serum for $1 \mathrm{hr}$ at room temperature. After washing the monolayers, HT-H $\{1\}$ or SNG-M (2) cells were added to the monolayers. $(D)$ Self-binding of COS-1 cells to monolayers of trophinin- and tastin-expressing COS- 1 cells. COS- 1 cells were transfected with pcDNAI vector alone (1) or a mixture of tastin and trophinin cDNAs (2-5). Monolayers of COS- 1 cells were pretreated with anti-GST551 (3), anti-GST552 (4), or anti-GST553 (5) antisera for $1 \mathrm{hr}$ at room temperature. In $B-D$, adhesion assays were conducted in the presence of 1 mM EDTA.
COS-1 cells transfected with a mixture of cDNA clones adhered to a monolayer of SNG-M cells. Surprisingly, however, COS-1 cells transfected with each clone individually failed to adhere to the SNG-M cells. Two clones necessary for cell adhesion were then identified (Fig. 1B). One cDNA clone is named trophinin, as it was cloned from trophoblastic cells. The second cDNA clone is named tastin, as this encodes a trophinin assisting protein.

\section{Characterization of trophinin}

The trophinin cDNA clone covers 2524 nucleotides with an open reading frame encoding 749 amino acids (Fig. 3A). Searches through the data base have shown no significant homology between trophinin and other known nucleotide or peptide sequences.

In vitro translation of this cDNA showed a major product at $61 \mathrm{kD}$ (Fig. 3B), which is in approximate agreement with the predicted molecular mass of $69 \mathrm{kD}$. Hydropathy analysis (Kyte and Doolittle 1982) predicted eight transmembrane domains (Fig. 3A,C). No cleavable signal sequence was found in trophinin. The presence of arginine residues at positions 43,48 , and 54 upstream of the predicted first transmembrane domain (Fig. 3A) suggests the possibility that these basic amino acid residues function as stop transfer during translocation of trophinin in the endoplasmic reticulum (ER) and that the amino-terminal segment (residues 1-66) localizes in the cytoplasm. Polyclonal antibodies against the amino-ter- minal region did not stain unpermeabilized cells but did stain cells after they were permeabilized (see Fig. 5A, below), supporting the hypothesis that the amino-terminal region localizes in the cytoplasm. In this region, there are three serine and threonine residues in a context that makes them potential phosphorylation sites for protein kinases (Fig. 3A,C; Kemp and Pearson 1990).

The most striking structural feature of trophinin is that $>90 \%$ of this molecule is made of tandem repeats of decapeptide sequences (Fig. 3D). There are a total of 69 such repeats. Within the repeats are three relatively long hydrophilic domains. Three glutathione $S$-transferase (GST) fusion proteins, each having the peptide sequences of the first, second, and third hydrophilic domains, designated GST551, GST552, and GST553, respectively, were produced in bacteria. Antibodies against these fusion proteins were raised (see Fig. $3 \mathrm{C}$ and Materials and methods for details). These antibodies stained unpermiabilized COS-1 cells transfected with trophinin cDNA (see staining with anti-GST553 antibodies in Fig. 4A,B, below). These antibodies also stained unpermeabilized HT-H cells and SNG-M cells, showing staining patterns very similar to those given by anti-trophinin antibodies raised against the amino-terminal domain of trophinin (Fig. 5A,B, below), suggesting that these three regions of trophinin are exposed on the cell surface.

To examine further whether trophinin is a plasma membrane protein, cell surface-labeling experiments were performed. Intact $\mathrm{HT}-\mathrm{H}$ cells were labeled with biotin-maleimide, a reagent that reacts with the sulfhy- 
Figure 2. Electron micrographs of the HT-H cells cocultured on a SNG-M cell monolayer. HT-H cells were added to a monolayer of SNG-M cells, and both cell types were cocultured for up to 4 days. The micrographs show the boundary of the two cell types at $10 \mathrm{~min}(A, B) 6 \mathrm{hr}(C)$, and 4 days $(D)$. $(A)$ An HT-H cell $(\mathrm{H}$, upper cell $)$ attached on a SNG-M cell (S) grown on a tissue culture plate. The HT-H cell has microvilli on the lower side (presumably an apical surface originally) facing the upper surface of the SNG-M cell. The basal surface of the HT-H cell is indicated by arrows. Bar, $5 \mu \mathrm{m}$. $(B)$ Higher magnification of the area shown indicated by brackets in $A$ ). Note that these two cell types contact via microvilli. (H) HT-H cell; (S) SNG-M cell. (C) HT-H (H, upper) and SNG-M (S, lower) cells at $6 \mathrm{hr}$ of coculture. Closer contact between the two cell types is seen. Note that the microvilli are flattened in both cell types. Tips of microvilli extended from one cell type appear to attach directly to the plasma membrane of the other cell type. The SNG-M cells at this stage of contact often show invagination activity (arrow). Bar, $1 \mu \mathrm{m}$. (D) An HT-H cell cocultured on a monolayer of the SNG-M cells for 4 days. Note the absence of microvilli on the surface of both the HT-H (H, upper) and SNG-M (S, lower) cells. The contact between these two cell types is mostly focal, and occasional development of an adherent junction (arrow) is detected.
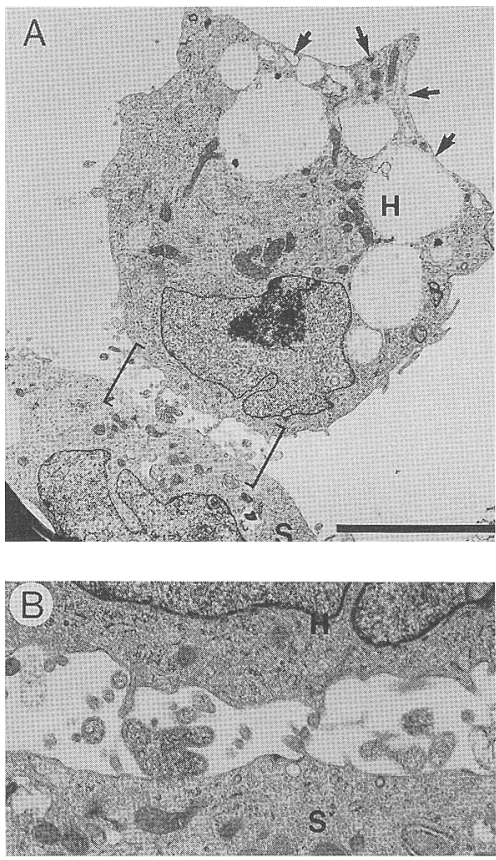
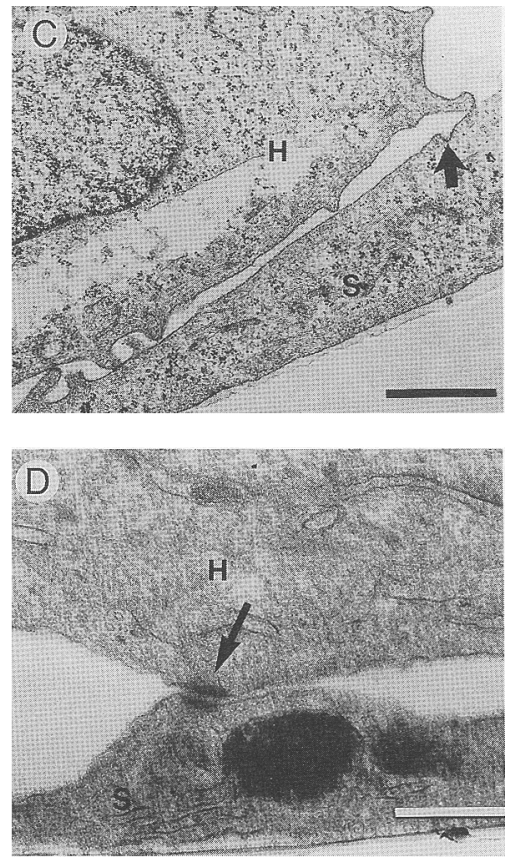
Bar, $0.5 \mu \mathrm{m}$.

dryl group of cysteine. ${ }^{1}$ Biotinylated cells were solubilized with NP-40. NP-40-insoluble material was solubilized further with SDS. Biotinylated (presumably cell surface proteins) were then recovered by avidin-agarose beads. Both avidin-bound and -unbound fractions were resolved by SDS-PAGE and were subjected to Western blot analysis with anti-trophinin antibodies. Western blots with anti-GST553 antibodies show three bands

Figure 3. Structure and characterization of trophinin and tastin. $(A)$ Nucleotide and deduced amino acid sequences of the trophinin cDNA clone. Single-letter amino acid symbols are used. The putative transmembrane domains are underlined, putative cytoplasmic domains are shown in italics, and putative cell surface domains are shown by boldface letters. Potential amino-linked and $O$-linked glycosylation sites are underlined. Potential site of serine and threonine residues for phosphorylation by casein kinase II and protein kinase $\mathrm{C}$ are shown by shadowed and underlined/shadowed letters, respectively. These sequence data are available from EMBL/ GenBank/DDBJ under accession number U04811. (B) SDS-polyacrylamide gel electrophoresis analysis of in vitro-translated products from trophinin and tastin cDNA. Numbers at right show positions of molecular mass markers. (Lane 1) Translated products of trophinin cDNA; (lane 2) translated products of tastin cDNA. $|C|$ A hydropathy plot of trophinin polypeptide. Settings of the parameters (peak minimal value, baseline value), including minimum length (16 amino acid residues) of a transmembrane helix, are identical to those proposed previously (Kyte and Doolittle 1982). Bars at the bottom indicate regions predicted for transmembrane helices. $(D)$ Tandem decapeptide repeats in trophinin. The amino acid sequence of trophinin from residue 69 to 743 is comprised of decapeptide repeats. $(E)$ Cell surface labeling and Western blot analysis of trophinin in HT-H cells. Intact HT-H cells were labeled with biotinmaleimide and subsequently solubilized with $1 \%$ NP-40. NP-40-insoluble material was solubilized further with $0.1 \%$ SDS. Each extract was incubated with avidin-agarose beads, separated into avidin-bound and -unbound fractions, and subjected to Western blot analysis using anti-trophinin (GST553) antibodies. (Lane 2) NP-40 extracted, and avidin-bound fractions; (lane 1) unbound fractions. (Lane 4) SDS-extracted and avidin-bound fractions; (lane 3) unbound fractions. Numbers at left show positions of prestained molecular mass markers. $(F)$ Nucleotide and deduced amino acid sequence of tastin cDNA clone. Single-letter amino acid symbols are used. Potential sites of serine, threonine, and tyrosine residues for phosphorylation by protein kinase C, cAMP/cGMP-dependent protein kinase, casein kinase II, MAP kinase, and tyrosine kinase are shown by underlined boldface, underlined, boldface, and shadowed letters, respectively. Potential sites of glycine residues for myristoylation are underlined. The region from amino acid residues 504 to 687 is rich in cysteines. Within this region, the peptide segment from residues 516 to 647 is made of four tandem repeats, each composed of 33 amino acids (marked by italics). These sequence data are available from EMBL/GenBank/DDBJ under accession number U04810. 
A

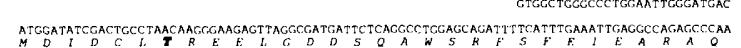

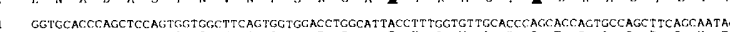

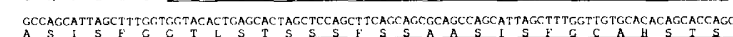

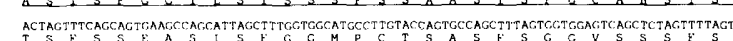

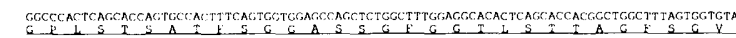

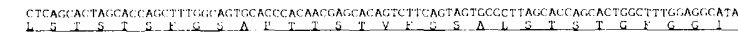

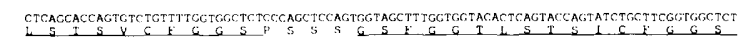

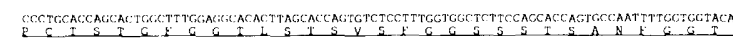

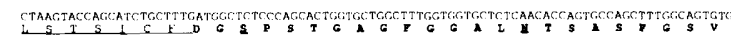

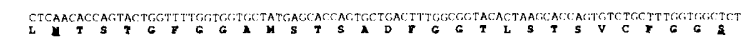

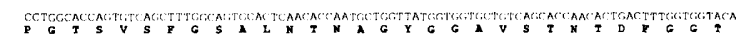

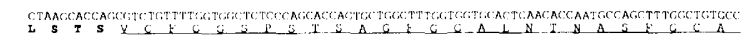

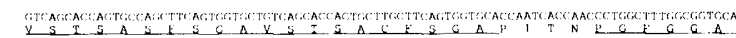

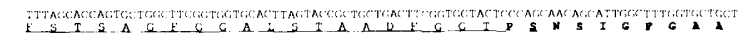

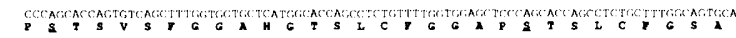

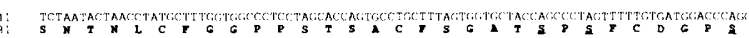

it A $\mathrm{z} \perp \mathrm{s}$

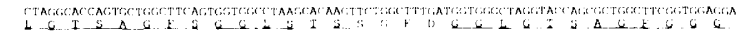

W

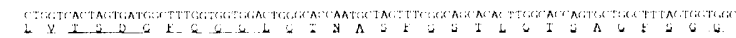

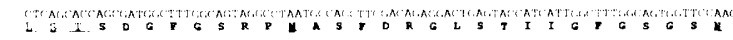

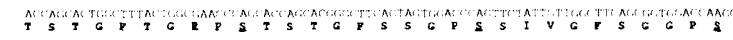

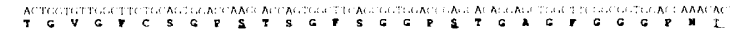

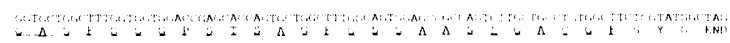

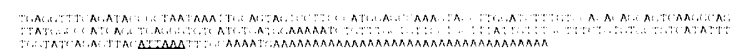

\section{D}

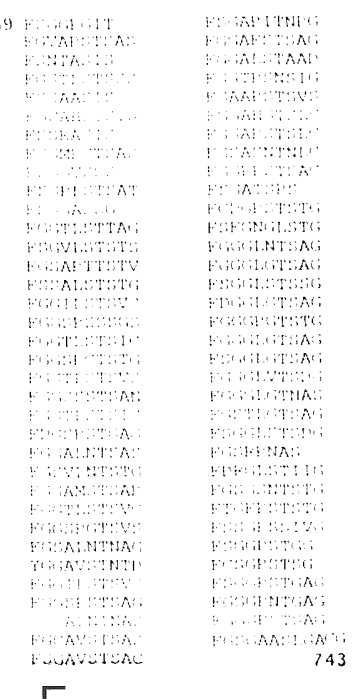

E

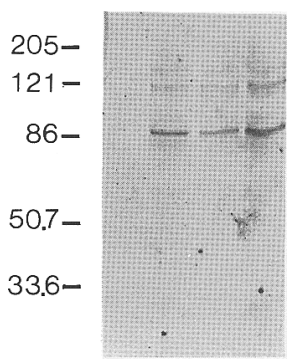

1234

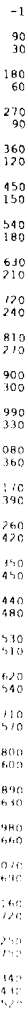

$\underset{60}{180}$

270

360
120

450
150

${ }_{189}^{540}$

120
240

810

900
100

990
390

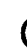

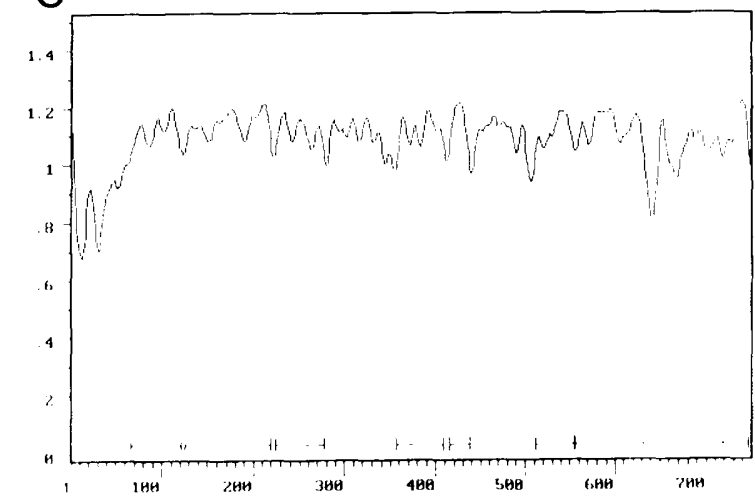

$\mathrm{F}$

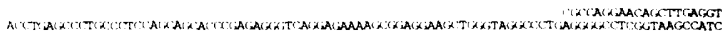

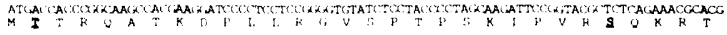

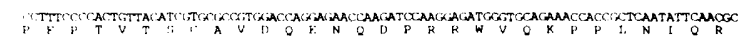

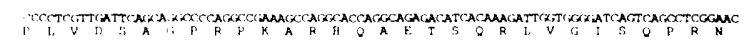

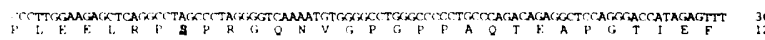

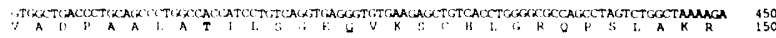

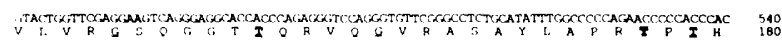

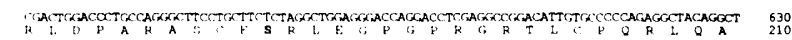

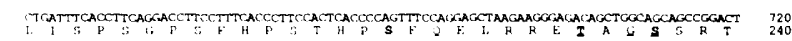

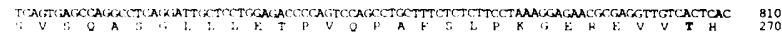

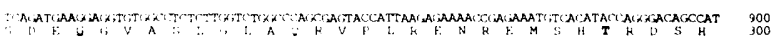

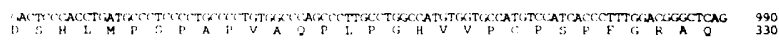

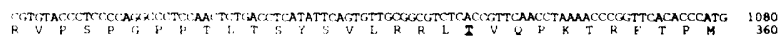

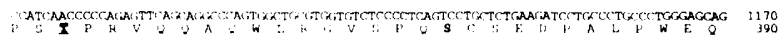

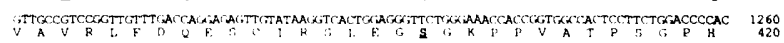

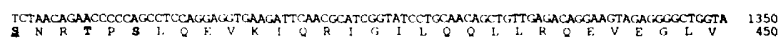

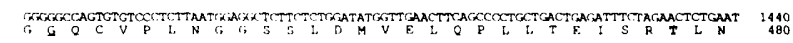

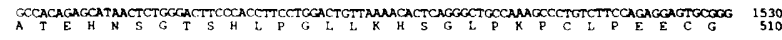

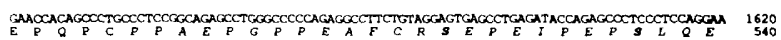

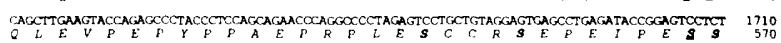

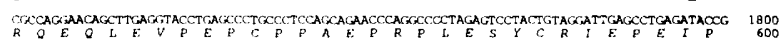

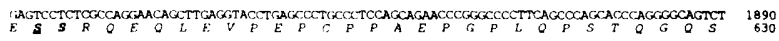

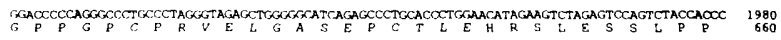
TGCTGCAGTCAGTGGCGTCCAGCAACCACCACCCTGATCTTCTCTRCCCAACACCCLCTTTGTCCCAGCCOCCCTATCTGCTCACTCCAG 2070 TCTTTGAGAOCCCCAGCAGGCCAGGCAGGCCTCACCAATCTCGCCCCCOCAACOCTAGCCCTCAGGGAGACCCTCAAATCGTGTPTANCC 2160 GCCATCCACTCCTTCACGAGGCTCGTCTCGACGATGAGTGTGCCTTTPACACCAGCCGAGCCTCTCCCTCACOCCOCACCCGGGTCTSC 2250

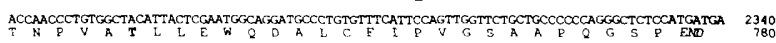

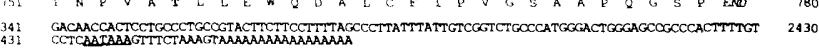

Figure 3. (See facing page for legend.) 
with apparent molecular masses of 90,120 , and $140 \mathrm{kD}$ in HT-H cells (Fig. 3E). ${ }^{2}$ The majority of trophinins were recovered in the avidin-bound fraction (lanes 2,4), suggesting that trophinin is exposed at the cell surface. Furthermore, a significant amount of trophinin was insoluble in NP-40 (lanes 1,2) and was extracted with SDS (lanes 3,4 ), suggesting that trophinin is associated with the cytoskeleton in HT-H cells. Similar results were obtained when SNG-M cells were analyzed by surface labeling and Western blot. These results collectively indicate that trophinin is an intrinsic plasma membrane protein. However, predicted topology of trophinin shown in Figure 3, A and C, is tentative. Further analysis is needed to define each cytoplasmic and cell surface domain of trophinin.

\section{Involvement of trophinin in homophilic cell adhesion}

The antibodies raised against the predicted cell surface domains of trophinin were examined for their effect on cell adhesion. Adhesion of HT-H or SNG-M cells to SNG-M cell monolayers was reduced significantly by pretreatment with Fab' fragment (not shown) as well as intact anti-GST553 antibodies (Fig. 1C). Preimmune sera of these antibodies or antibodies raised against the amino-terminal region of trophinin did not show any effect on cell adhesion.

If trophinin mediates homophilic cell adhesion, COS-1 cells that are cotransfected with trophinin and tastin should be self-adhesive. COS-1 cells transfected with a mixture of trophinin and tastin cDNAs aggregated when they were left in suspension. These COS-1 cells adhered to monolayers of cotransfected COS-1 cells, and this binding was reduced significantly by pretreatment with the antibodies raised against predicted cell surface domains of trophinin (Fig. 1D).

Direct binding of trophinin to the cell surfaces of trophinin-expressing cells was examined. Fusion proteins (GST551, GST552, and GST553) were labeled with biotin and added to monolayers of HT-H and SNG-M cells. Binding of biotinylated proteins to the cell surface was detected under a fluorescence microscope using FITCavidin. These fusion proteins also bound to the cell surface of COS-1 cells cotransfected with trophinin and tastin (Fig. 4C), whereas neither unfused GST nor GST fused to the amino-terminal domain (1-66) of trophinin showed such binding (not shown). These results indicate that soluble peptides of the cell surface domain of trophinin have the property of binding to the cell surface of trophinin-expressing cells. This supports the hypothesis that trophinin mediates homophilic cell adhesion.

\section{Characterization of tastin}

Tastin cDNA covers 2578 nucleotides with an open reading frame encoding 778 amino acids (Fig. 3F). Searches through the data bank have revealed no significant homology between tastin and any other protein in the data base. ${ }^{3}$

In vitro translation of the tastin cDNA showed a prominent product of $80 \mathrm{kD}$ (Fig. 3B), consistent with the predicted molecular mass of $83 \mathrm{kD}$. Hydropathy analysis (Kyte and Doolittle 1982) showed no obvious signal for secretory protein or transmembrane domains. Therefore, tastin is probably a cytoplasmic protein.

Tastin is rich in prolines that account for $16.2 \%$ of the total amino acids of this protein. The region from amino acid residues 504 to 687 is rich in cysteines (Fig. 3F). Within this region, the peptide segment from 516 to 647 is made of four tandem repeats, each composed of 33 amino acids. Tastin contains many serines and threonines and one tyrosine, whose surrounding amino acid residues conform to motifs for phosphorylation sites by protein kinases (Fig. 3F). Two cAMP/cGMP-dependent phosphorylation sites are predicted at positions 235 and 350 . Among the 16 protein kinase $C$ phosphorylation sites predicted, the threonine at position 179 match the consensus sequence of $\mathrm{R}(\mathrm{K})-X-X-\mathrm{T}(\mathrm{S})-X-\mathrm{R}-(\mathrm{K})$ most closely (Kemp and Pearson 1990). There are a total of 11 serine and threonine residues predicted for casein kinase II phosphorylation sites. Threonines at positions 177 and 363 are within the consensus sequence for the mitogenactivated protein (MAP) kinase phosphorylation site P-X-S(T)-P (Gonzalez et al. 1991).

Tastin is necessary for trophinin to function as a cell adhesion molecule (Fig. 1B,C). When trophinin was expressed in COS-1 cells without tastin, trophinins distributed diffusely on the cell surface (Fig. 4A). However, when trophinin and tastin were coexpressed, trophinins showed a clustered distribution (Fig. 4B), indicating that tastin induces the clustering of trophinin. This implies that the role of tastin in cell adhesion is to create multivalent trophinin patches that serve as potent adhesion sites.

\section{Subcellular localization of trophinin and tastin in HT-H and SNG-M cells}

The localization of trophinin and tastin in HT-H and SNG-M cells was examined immunocytochemically. Anti-trophinin antibodies detected this protein both in HT-H cells and SNG-M cells (Fig. 5A,B). The trophinin molecules apparently cluster, showing a lacy pattern in these cells. Trophinin in HT-H and SNG-M cells (Fig.

\footnotetext{
${ }^{2}$ Because these molecular masses are much larger than the expected $69 \mathrm{kD}$, Western blot was performed with another antibody directed against the amino-terminal region of trophinin (see anti-peptide antibodies in legend to Fig. 5). Western blot analysis with the anti-peptide antibodies detected the same three bands, whereas preimmune sera did not detect them. Therefore, we conclude that the bands shown in Figure $3 \mathrm{E}$ are trophinin. Although it is possible that alternative splicing of the trophinin gene in HT-H and SNG-M cells results in the production of altered trophinin polypeptides, the cause of differences in molecular weights and in the three bands of trophinin reains unknown.

${ }^{3}$ Computer searches using the nucleotide sequence of tastin revealed that the complementary sequence between nucleotide positions 2057 and 2340 matches the sequence of HFBCL29 cDNA (GenBank accession no. M85643) isolated from a human fetal brain cDNA library. It appears that the HFBCL29 sequence was recorded in the antisense direction.
} 

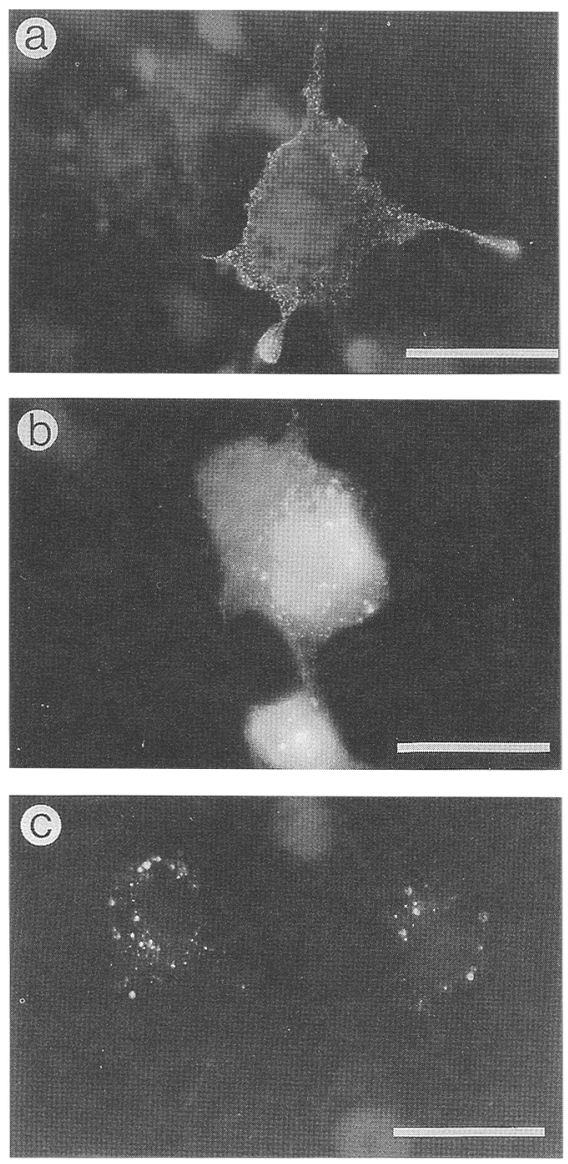

Figure 4. Fluorescence micrographs of transfected COS-1 cells. COS- 1 cells were transfected with trophinin cDNA alone $(a)$ or with a mixture of trophinin and tastin cDNAs $(b)$. Cells were stained with anti-trophinin (GST553) antibodies followed by an FITC-conjugated $F\left(a b^{\prime}\right)_{2}$ fragment of goat antirabbit IgG (Cappel). (c) Binding of GST553 fusion protein (the predicted third outer cellular domain of trophinin) on the surface of COS-1 cells transfected with a mixture of trophinin and tastin cDNAs. Fusion protein GST553 was produced in bacteria, purified using glutathione-Sepharose beads, biotinylated with biotinamidocaproate- $N$-hydroxysuccinimide, and added to the monolayer of transfected COS-1 cells. Binding of GST553 fusion protein to COS-1 cells was visualized using FITC-conjugated avidin. Bar, $20 \mu \mathrm{m}$.

$5 \mathrm{~A}, \mathrm{~B} \mid$ appears well organized compared with that in COS-1 cells, which are transfected with trophinin and tastin cDNAs (Fig. 4B).

Anti-tastin antibodies detected this protein both in HT-H and SNG-M cells (Fig. 5C,D). Tastin is seen as a diffuse cytoplasmic protein as well as being found in fibers. The fibers spread from the perinuclear region toward the edge of the cells, suggesting that tastin associates with the cytoskeleton.

Expression of trophinin and tastin in various human tissues

Northern blot analysis using cDNA probe for trophinin showed a signal at $3.5,7.5$, and $10 \mathrm{~kb}$ in poly $(\mathrm{A})^{+}$RNA isolated from both HT-H and SNG-M cells. The analysis using tastin cDNA as a probe showed a signal at $3.2 \mathrm{~kb}$ (major) and $3.5 \mathrm{~kb}$ (minor) in poly(A) ${ }^{+}$RNA isolated from both HT-H and SNG-M cells. A Northern blot of several human tissues detected weak signals for trophinin and tastin mRNAs in placenta, lung, and liver. However, immunohistochemistry of these tissues showed that only macrophages present in the tissues were positive. These results indicate that trophinin and tastin are normally not expressed in various types of human cells, with the exception of macrophages.

\section{Expression of trophinin and tastin during implantation}

In human endometrium, trophinin was not detected at the proliferation stage (days $6-13)$ or at the ovulation stage (day 14); however, trophinin was detected on the apical plasma membranes of the endometrial surface epithelium on day $16 / 17$ (early secretory phase) (Fig. 5E,F). In middle and late secretory phases (days 20-28), trophinin was detected in mucus, apparently shed from epithelia (Fig. 5G). Similarly, tastin was detected in the trophinin-expressing endometrial epithelium cells on day 16/ 17 and in mucus in middle and late endometrium but was not detected at the proliferation and ovulation stages. These observations suggest that trophinin and tastin are expressed in surface epithelia at an early secretory phase and are quickly down-regulated from the cell surface.

In human placenta from early (5-10 weeks) pregnancy, trophinin and tastin were found in the lysosomes of syncytiotrophoblasts (not shown) but were not detected in placenta tissues later in pregnancy. These observations suggest that trophinin and tastin were expressed in the trophoblasts at the earliest stage in placenta but disappeared from the surface within the first few weeks of pregnancy.

Strong expression of trophinin was detected in the apical plasma membranes of the trophectoderm of monkey blastocysts (Fig. 5H). It is noteworthy that expression of the trophinin is more elevated at the embryonic pole than at the mural pole. Expression of tastin follows the same profile as that of trophinin in the blastocyst. Such a polarized distribution of trophinin and tastin may be consistent with the observations that in both primates and humans a blastocyst attaches to endometrial epithelium at its embryonic pole (Knoth and Larsen 1972; Enders et al. 1981; Lindenberg et al. 1986).

Figure 5I shows a section of monkey uterus that includes the implantation site. Trophinin was detected both in trophoblasts of the blastocyst and in endometrial epithelium cells (see inset), as well as in cytotrophoblasts, hypertrophic endometrial epithelium cells, and cells at anchoring villi.

\section{Cell adhesion activity of trophinin-and tastin-expressing endometrial epithelium}

To test whether naturally expressed trophinin and tastin could mediate cell adhesion, HT-H, SNG-M, and COS-1 cells were added to the endometrial tissue shown in Figure 5E. Both HT-H and SNG-M cells adhered to the site 

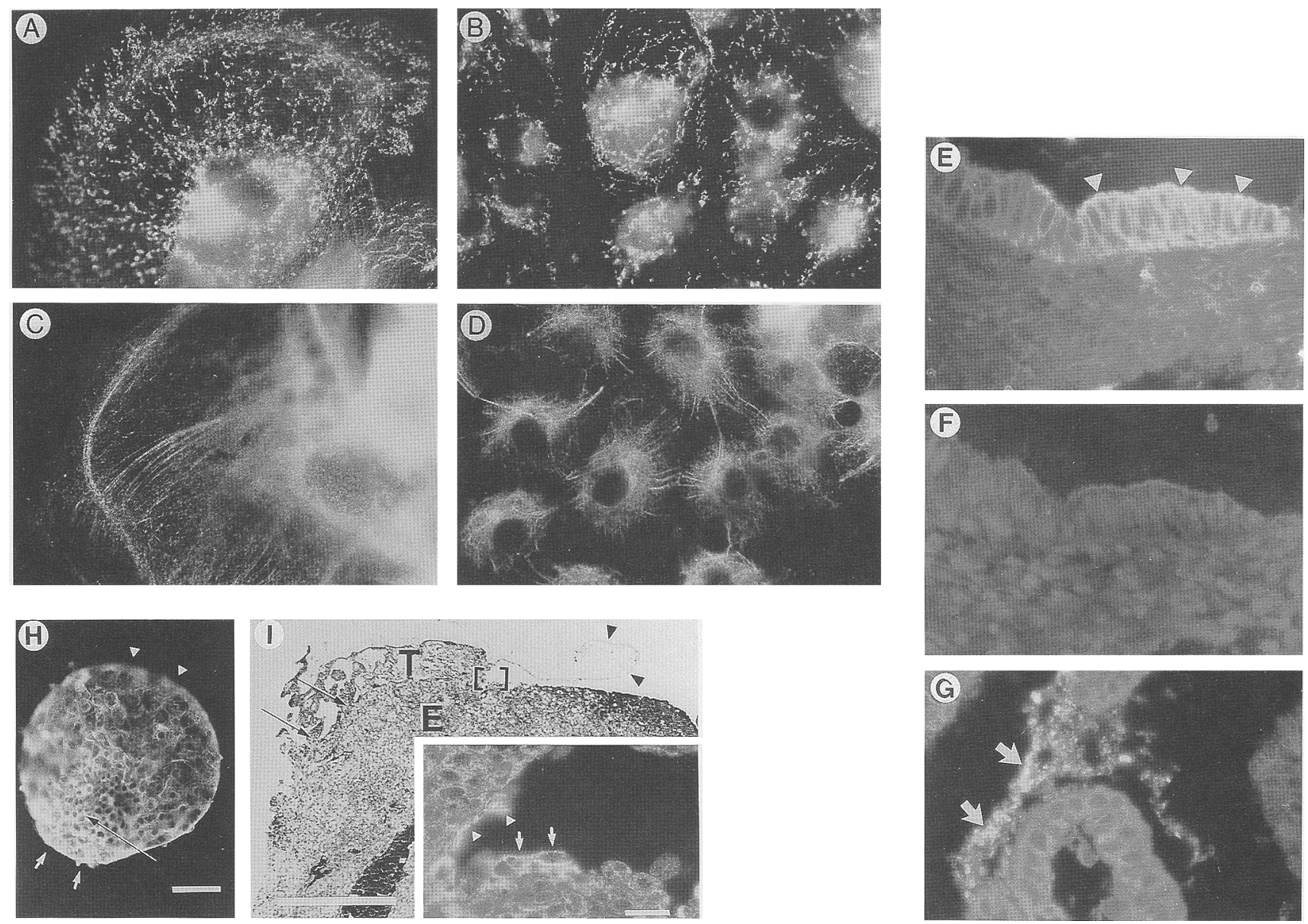

Figure 5. Fluorescence micrographs showing expression of trophinin and/or tastin in cultured cells and the cells involved in implantation. Shown are immunofluorescence micrographs of HT-H cells $(A \mid$ and SNG-M cells $(B)$ stained with anti-trophinin antibodies raised against the amino-terminal region of trophinin. Immunofluorescence micrographs of HT-H cells $(C)$ and SNG-M cells $(D)$ stained with anti-tastin antibodies are shown. $(E)$ Immunofluorescence micrograph of a surface epithelium of day $16 / 17$ (early secretory phase) endometrium. Trophinins are detected on the apical plasma membranes (arrowheads). (F) Immunofluorescence micrograph of the same series of sample shown in $E$ stained with preimmune serum. (G) Presence of trophinin in mucus in endometrial gland at late secretory phase. Magnification, $650 \times(A-D) ; 575 \times(E-G) .(H)$ Immunofluorescence micrograph of rhesus monkey blastocyst stained with anti-trophinin antibodies. Inner cell mass is shown by a long arrow. Note that cells at the embryonic pole $/$ short arrows) were stained more intensely than those at the mural pole (arrowheads). Bar, $25 \mu \mathrm{m}$. (I) A light micrograph of macaque monkey uterus tissue with an implanted and $\sim 15$-day blastocyst. Arrowheads show cytotrophoblasts of blastocyst. Long arrows show anchoring villi (trophoblasts penetrating the endometrial epithelium). (T) Trophoblasts. (E) Hypertrophic endometrial epithelium. Bar, 200 $\mu \mathrm{m}$. (Inset) An immunofluorescence micrograph of higher magnification of the area marked by a parenthesis. Both trophoblast (arrowheads) and endometrial epithelium cells (arrows) are stained by anti-trophinin antibodies. Bar, $10 \mu \mathrm{m}$. In $A, B, E, G, H$, and $I$, the antibodies raised against a synthetic peptide of the amino-terminal region (residues 23-31) of trophinin were used.

of endometrial surface epithelium expressing trophinin, and such adhesion was lost by treatment of the tissue with anti-trophinin (anti-GST553) antibodies (not shown). COS-1 cells cotransfected with trophinin and tastin cDNAs adhered to the trophinin-expressing site of endometrium, whereas untransfected COS-1 cells did not show any sign of adhesion.

\section{Discussion}

Two novel molecules, trophinin and tastin, have been identified by expression cDNA cloning. Trophinin is an intrinsic membrane protein and is directly responsible for homophilic cell adhesion; tastin is a cytoplasmic protein and is necessary for trophinins to function as adhesion molecules.

Although the simultaneous cloning of two genes is a low probability event, we believe that transfection of a cDNA library by electroporation was the key to the success of this experiment. Because electroporation opens pores in the plasma membrane of cells and allows plasmid DNA to enter through such pores, the amount of DNA entering the cells is dependent on the concentration of DNA in the solution. We also used a high con- 
centration of plasmid DNA $(100 \mu \mathrm{g} / \mathrm{ml})$ in the electroporation, whereas the standard procedure uses $20 \mu \mathrm{g} / \mathrm{ml}$ of plasmid DNA. This high concentration of plasmid DNA during electroporation thus leads to cotransfection of many plasmid DNAs into a single cell. Another factor for coexpression cloning is the number of recipient cells. As described (see Materials and methods for details), we used enormous numbers of COS-1 cells for the first $\left(1 \times 10^{8}\right.$ cells $)$ and second $\left(1 \times 10^{7}\right.$ cells $)$ screenings.

Present studies also show that cytoplasmic protein tastin is necessary for the cell adhesion molecule trophinin to function. Many studies indicate that the functions of cell adhesion molecules are determined by their association with cytoplasmic proteins and cytoskeletal structures (Hynes 1992; Garrod 1993; Gumbiner 1993; Stappert and Kemler 1993). The association between the adhesion molecule and the cytoskeleton is also suggested in this study. Thus, the cytoplasmic domain of trophinin might associate with tastin, which apparently associates with the cytoskeleton. Such association would restrict the distribution of trophinins in the plasma membrane, creating highly concentrated trophinin patches in plasma membranes that may function as efficient adhesion sites (Fig. 4). We have made a mutant trophinin lacking the amino-terminal region, predicted cytoplasmic domain. When this mutant and tastin were coexpressed in COS-1 cells, mutant trophinin did not cluster and COS-1 cells did not exhibit adhesion activity (J. Zara and M.N. Fukuda, unpubl.). Therefore, the cytoplasmic domain of trophinin is necessary for cell adhesion.

Potential involvement of trophinin and tastin in embryo implantation is supported by the following evidence: (1) Human endometrium is under strict hormonal controls and is generally not permissive to implantation. Trophinin and tastin are not found in the proliferative phase and ovulation phase of human endometrium. These molecules are expressed in the endometrium only on the surface epithelium at the time expected for an implantation window (Yoshinaga 1988; Harper 1992). (2) Strong expression of trophinins and tastins were detected at the trophectoderm surface of the monkey blastocyst. Expression of these molecules was particularly strong at the embryonic pole where the blastocyst adheres to the endometrium (Enders et al. 1981; Lindenberg et al. 1986). (3) Trophinins were detected in both trophoblasts and endometrial epithelium cells at the monkey blastocyst implantation site.

Strictly regulated expression of trophinin and tastin in vivo and their unique cell adhesion activity displayed at apical surfaces of trophoblastic HT-H cells and endometrial epithelial SNG-M cells suggest the possibility that these molecules are involved in the initial adhesion of the blastocyst to the endometrium.

The study of embryo implantation at the molecular level is one of the most difficult subjects to study in developmental biology. Information provided in this paper and materials, such as cDNAs and antibodies, that became available from the present study will be useful for future studies of embryo implantation.

\section{Materials and methods}

Cell lines and cell culture

Trophoblastic HT-H cells were separated from undifferentiated HT-H cells as described (Izhar et al. 1986), subcloned, and used in the present study. Endometrial adenocarcinoma cell lines Hec1A, RL95-2, and AN3CA were obtained from American Tissue Culture Collection. All cell lines have been cultured in Dulbecco's modified Eagle medium (DMEM) containing $10 \%$ fetal bovine serum, $2 \mathrm{mM}$ glutamine, $100 \mathrm{U} / \mathrm{ml}$ of penicillin, and $100 \mu \mathrm{g} / \mathrm{ml}$ of streptomycin.

\section{Cell adhesion assay}

HT-H cells were metabolically labeled with $\operatorname{Tran}^{35} \mathrm{~S}$-label (New England Nuclear) in methionine- and cysteine-free RPMI medium for $20 \mathrm{~min}$ and chased with complete medium for $2 \mathrm{hr}$. The ${ }^{35} \mathrm{~S}$-labeled HT-H cells were detached from the bottom of the tissue culture dish using cell dissociation solution (Specialty Media, Lavalette, NJ) supplemented with 1 mM EDTA. The cells were pelleted by centrifugation and resuspended in HEPES-buffered saline (HBS). Cell suspensions $\left(0.2 \mathrm{ml}, 5 \times 10^{4}\right.$ cells) were added to a monolayer of the endometrium epithelial cells that had been grown on the bottom of a 24-well tissue culture plate. The HT-H cells that did not adhere to the monolayer were washed three times with HBS with or without $1 \mathrm{~mm}$ EDTA. The cells remaining in each well were solubilized with $0.5 \mathrm{ml}$ of $0.5 \mathrm{~N} \mathrm{NaOH}$ and $1 \%$ SDS, and radioactivity was counted. Cell adhesion assays were also conducted using fixed cell monolayers. Cells grown on the bottom of a 24-well tissue culture plate were treated with $1 \%$ paraformaldehyde in PBS at room temperature for $15 \mathrm{~min}$ and were used for cell adhesion assays in the same manner described above.

\section{Production of antibodies}

Anti-trophinin (GST551, GST552, and GST553) antibodies were raised as follows: A cDNA encoding one of the hydrophilic domains (residues $278-364,441-512$, or 634-719) within the decapeptide repeats was amplified by polymerase chain reaction (Saiki et al. 1988) and was ligated into pGEX-4T-1 vector (Pharmacia, Piscataway, NJ). Escherichia coli $\mathrm{HBlOl}$ was transformed with the plasmid vector, and a GST fusion protein was produced. The fusion protein was purified by glutathione-agarose beads and used for rabbit immunization.

The most antigenic sequence of trophinin and tastin was predicted by computer program (Hopp and Wood 1983). Peptides CFEIEARAQE (for trophinin, amino acid residues 23-31) and CDQENQDPRR (for tastin, amino acid residues 41-49) were synthesized. The first cysteine residue at the amino terminus of each peptide was added to link the peptide to keyhole limpet hemocyanin $(\mathrm{KLH})$ by conjugation with meta-maleimidobenzoyl- $N$-hydroxysuccinamide ester (Kitagawa and Aikawa 1976). Rabbits were immunized with either of the peptide-KLH conjugates, and antisera were obtained. Anti-peptide antibodies were purified by protein A affinity column chromatography followed by peptide-Sepharose $4 \mathrm{~B}$ affinity chromatography as described (Richardson et al. 1985).

\section{Electron microscopy}

SNG-M cells were cultured in a Falcon $3001(25 \times 10 \mathrm{~mm})$ tissue culture dish to $50 \%$ confluence. The HT-H cells were detached from the tissue culture dish by trypsin/EDTA treatment and were added to a monolayer of SNG-M cells. The two cell types were cultured together for up to 4 days. For transmission elec- 
tron microscopy, the cells were fixed at room temperature in freshly prepared fixative $\left(10 \mathrm{mmoles} / \mathrm{liter}\right.$ of $\mathrm{NaIO}_{4}, 75$ mmoles/liter of lysine, $37.5 \mathrm{mmoles} /$ liter of sodium phosphate buffer, $2 \%$ paraformaldehyde at $\mathrm{pH} 6.2$ ) for $15 \mathrm{~min}$. After washing with phosphate buffer, the cells were treated with glutaraldehyde and processed for electron microscopy as described previously (Klier et al. 1977). A Hitachi K-600 electron microscope was used.

\section{Expression cDNA cloning of adhesion molecules}

Coexpression cloning of trophinin and tastin was carried out as follows. Poly $\mid \mathrm{A})^{+}$RNA was prepared from freshly harvested HT-H cells. A unidirectional cDNA expression library was constructed in pcDNAI vector. A custom-ordered cDNA library construction was provided by Invitrogen (La Jolla, CA), which consists of $2 \times 10^{6}$ independent clones with an insert size ranging from 0.5 to $3.0 \mathrm{~kb}$. COS- 1 cells $\left(1 \times 10^{8}\right.$ cells total, $1 \times 10^{7}$ to $\sim 0.5 \times 10^{7}$ cells $/ \mathrm{ml}$ ) were suspended in PBS containing plasmid DNA $(100 \mu \mathrm{g} / \mathrm{ml})$. Transfection was performed by electroporation using a Gene Pulser (Bio-Rad, Hercules, CA) at $0.4 \mathrm{kV}$ with a capacitance of $125 \mu \mathrm{F}$. The transfected COS-1 cells were cultured for $48 \mathrm{hr}$ in complete DMEM and subjected to adhesion assays. The single-cell suspensions of COS- 1 cells were overlaid to a fixed monolayer of SNG-M cells in the presence of $1 \mathrm{~mm}$ EDTA. After 20 min, nonadherent COS- 1 cells were removed by washing the monolayer with buffer containing EDTA. About $1 \times 10^{4}$ COS- 1 cells appeared to be attached. The COS- 1 cells remaining on the SNG-M cells were detached by flushing the buffer and were then added to a new fixed monolayer of SNG-M cells. About $1 \times 10^{3}$ COS- 1 cells appeared to be attached. Plasmid DNAs were recovered from the twice-adhered COS-1 cells, were amplified in E. coli MC1061/P3 cells, and were used for the second round of screening.

A second screening was carried out in the same manner as the first except that the number of the cells transfected was scaled down as follows: COS- 1 cells $\left(1 \times 10^{7}\right.$ cells $)$ were transfected with plasmid DNA recovered from the adherent COS-1 cells in the first screen. Twice-adhered COS-1 cells were selected in the same manner as described above. About $2 \times 10^{3}$ COS- 1 cells adhered to the first SNG-M monolayer and about $1 \times 10^{3}$ COS- 1 cells adhered to the second SNG-M monolayer. E. coli MC1061/ P3 cells were transformed by plasmid DNA obtained after the second round of screening.

Two hundred clones were chosen and divided into 10 groups. COS-1 cells transfected with one of the groups or a mixture of the 20 clones adhered to a monolayer of the SNG-M cells. However, COS-1 cells transfected with each clone individually failed to adhere to the SNG-M cells. The 20 clones were tested again as a mixture, eliminating each clone one by one. Finally, the adhesion assay showed that a mixture of two cDNAs was necessary for COS-1 cells to adhere to SNG-M cells.

\section{Nucleotide sequence analysis}

Nucleotide sequences were analyzed by the dideoxy nucleotide chain-termination method of Sanger et al. (1977) using a modified T7 DNA polynuclease (Sequenase, U.S. Biochemical, Cleveland, $\mathrm{OH}$ ). The nucleotide sequence of trophinin cDNA was determined from restriction fragments subcloned into Bluescript from nested deletion mutants generated by exonuclease III (Boehringer Mannheim, Indianapolis, IN). The nucleotide sequence of tastin cDNA was determined using oligonucleotide primers. Editing and analysis of the sequence was done using DNASIS (Hitachi, Tokyo, Japan) and PCGENE (Intelligenetics, Mountain View, CA) software programs. Sequence comparisons with the data bases were performed using the BLAST network program (National Center for Biotechnology Information, NIH, Bethesda, MD) (Altschul et al. 1990).

\section{Northern blot}

Total RNA was isolated from HT-H cells, SNG-M cells, and COS-1 cells by the acid-guanidine/phenol/chloroform method (Chirgwin et al. 1979|. Poly|A ${ }^{+}$RNA was prepared using oligo(dT)-cellulose affinity chromatography. Five micrograms of poly $(\mathrm{A})^{+}$RNA was separated in a $1 \%$ agarose-formaldehyde gel. The RNA was transferred to a nitrocellulose filter and fixed by heating at $80^{\circ} \mathrm{C}$ for $2 \mathrm{hr}$. Prehybridization and hybridization were performed as described by Thomas (1980). A human multiple-tissue Northern blot filter (MTN-1 filter, Clontech, Palo Alto, CA) was also processed in the same manner described above.

\section{In vitro translation}

The plasmid cDNA clones were subjected to in vitro translation using a T7 RNA polymerase promoter, in rabbit reticulocyte lysate (Promega, Madison, WI), and using RNA polymerase in the presence of $\left[{ }^{35} S\right]$ methionine. The products were separated on a SDS-polyacrylamide gel and visualized by autoradiography.

\section{Cell surface biotin labeling and Western blot}

HT-H and SNG-M cells were scraped from the tissue culture plate using a rubber policeman. After washing the cells with cold PBS, $20 \mu \mathrm{l}$ of dimethylformamide containing $10 \mu \mathrm{g}$ of biotin-maleimide (Sigma, St. Louis, MO) was added to the cell suspension $\left(1 \times 10^{6}\right.$ cells in $1 \mathrm{ml}$ of $\left.\mathrm{PBS}\right)$, and biotinylation proceeded for $1 \mathrm{hr}$ on ice. After washing the cells with cold PBS, cells were lysed with PBS containing $1 \%$ NP-40. NP-40-insoluble material was dissolved further with $0.1 \%$ SDS as described (Oshima et al. 1983). Each cell lysate was mixed with avidinagarose beads (Sigma) and separated into avidin-bound and -unbound fractions. Proteins in each fraction were resolved by SDS-polyacrylamide gel electrophoresis and analyzed by Western blot using anti-GST553 antibodies. The Western blot was performed as described (Towbin et al. 1979), except an ECL kit (Amersham, Buckinghamshire, UK) was used for the detection of the immunoreactive bands.

\section{Immunofluorescence microscopy}

Immunostaining was carried out in the same manner as described previously (Aoki et al. 1992). Briefly, HT-H cells, SNG-M cells, and transfected COS-1 cells were grown on glass coverslips placed in a Falcon 3005 tissue culture dish for 2-3 days. The cells were fixed at room temperature for $15 \mathrm{~min}$ with $1 \%$ paraformaldehyde in PBS and permeabilized with $0.1 \%$ saponin in PBS. An FITC-conjugated F $\left(\mathrm{ab}^{\prime}\right)_{2}$ fragment of goat antirabbit IgG (Cappel, Durham, NC) was used for second antibodies. Controls without the first antibodies were taken in each experiment. The cells were examined under a Zeiss Axioplan fluorescence microscope or a Zeiss LSM410 confocal laser scanning microscope.

Paraffin-embedded tissue sections of human endometrium and monkey uterus were deparaffinized with xylene and ethanol. To recover antigenic activities, deparaffinized tissue sections were microwaved in $10 \mathrm{~mm}$ citrate buffer ( $\mathrm{pH}$ 6.0) (Shi et al. 1991). Immunoreaction then proceeded in the same manner as described above. 


\section{Acknowledgments}

We thank Dr. Allen C. Enders at the University of California at Davis for providing us with monkey implantation site samples and for his helpful comments, Dr. Don P. Wolf at Oregon Health Science University for providing us with monkey blastocysts, Drs. Osamu Yamagami and Tsutomu Katsuyama at Shinshu University, Japan, for collecting endometrium biopsy samples. We also thank Dr. Russell Doolittle at the University of California at San Diego for helpful suggestions, Drs. Erkki Ruoslahti, Robert G. Oshima, and Yu Yamaguchi for their critical reading of the manuscript, and Ms. Leslie DePry for her assistance in typing the manuscript. T.S. is a fellow of the U.S. Army Medical Research and Development Command, Breast Cancer Research Program. This study has been supported by National Institutes of Health grant RO1DK37016 to M.N.F.

The publication costs of this article were defrayed in part by payment of page charges. This article must therefore be hereby marked "advertisement" in accordance with 18 USC section 1734 solely to indicate this fact.

\section{References}

Altschul, S.F., W. Gish, W. Miller, E.W. Myers, and D.J. Lipman. 1990. Basic local alignment search tool. I. Mol. Biol. 215: 403-410.

Andrews, P.W., P.N. Goodfellow, and I. Damjanov. 1983. Human teratocarcinoma cells in culture. Cancer Surv. 2: 4173.

Aoki, D., N. Lee, N. Yamaguchi, C. Dubois, and M.N. Fukuda. 1992. Golgi retention of a trans-golgi membrane protein, galactosyltransferase, requires cysteine and histidine residues within the membrane-anchoring domain. Proc. Natl. Acad. Sci. 89: 4319-4323.

Aplin, J.D. 1991. Implantation, trophoblast differentiation and haemochorial placentation: Mechanistic evidence in vivo and in vitro. J. Cell Sci. 99: 681-692.

Armant, D.R., H.A. Kaplan, and W.I. Lennarz. 1986. Fibronectin and laminin promote in vitro attachment and outgrowth of mouse blastocysts. Dev. Biol. 116: 519-523.

Chirgwin, J.M., A.Z. Przybyla, R.J. MacDonald, and W.J. Rutter. 1979. Isolation of biologically active ribonucleic acid from sources enriched in ribonuclease. Biochemistry 18: 5294 5299.

Ducibella, M., D. Anderson, J. Aalberg, and W.C. DeWolf. 1982. Cell surface polarization, tight junctions and eccentric inner cells characterize human teratocarcinoma embryoid bodies. Dev. Biol. 94: 197-205.

Enders, A.C., D.J. Chavez, and S. Schlafke. 1981. Comparison of implantation in utero and in vitro. In Cellular and molecular aspects of implantation (ed. S.R. Glasser and D.W. Bullock), pp. 365-382. Plenum Press, New York.

Farach, M.C., J.P. Tang, G.L. Decker, and D.D. Carson. 1987. Heparin/heparan sulfate is involved in attachment and spreading of mouse embryos in vitro. Dev. Biol. 123: 401410.

Garrod, D.R. 1993. Desmosomes and hemidesmosomes. Curr. Opin. Cell Biol. 5: 30-40.

Gonzalez, F., D. Raden, and R. Davis. 1991. Identification of substrate recognition determinants for human ERKl and ERK2 protein kinases. J. Biol. Chem. 266: 22159-22163.

Gumbiner, B.M. 1993. Proteins associated with the cytoplasmic surface of adhesion molecules. Neuron 11: 551-564.

Harper, M.J. 1992. The implantation window. Baillieres Clin. Obstet. Gynaecol. 6: 351-371.

Hopp, T.P. and K.R. Wood. 1983. A computer program for pre- dicting protein antigenic determinants. Mol. Immunol. 20: $483-489$.

Hynes, R.O. 1992. Integrins-versatility, modulation and signalling in cell adhesion. Cell 69: 11-25.

Ishiwata, I., S. Nozawa, T. Inoue, and H. Okumura. 1977. Development and characterization of established cell lines from primary and metastatic regions of human endometrial carcinomas. Cancer Res. 37: 1777-1785.

Izhar, M., P. Siebert, R.G. Oshima, W.C. DeWolf, and M.N. Fukuda. 1986. Trophoblastic differentiation of human teratocarcinoma cell line HT-H. Dev. Biol. 116: 510-518.

John, N.J., M. Linke, and H.-W. Denker. 1993. Quantitation of human choriocarcinoma spheroid attachment to uterine epithelial cells monolayers. In Vitro Cell. Dev. Biol. 29A: 461468.

Kaufman, M.H. 1985. The origin, properties and fate of trophoblast in the mouse. In Biology of trophoblast (ed. Y.W. Loke and A. Whyte), pp. 23-68. Elsevier Scientific, Amsterdam, The Netherlands.

Kemp, B.E. and R.B. Pearson. 1990. Protein kinase recognition sequence motif. Trends Biochem. Sci. 15: 342-346.

Kimber, S.J., S. Lindenberg, and A. Lundblad. 1988. Distribution of some Gal $\beta 1-3(4)$ GlcNAc related carbohydrate antigens on the mouse uterine epithelium in relation to the peri-implantation period. I. Reprod. Immunol. 12: 297-313.

Kitagawa, T. and T. Aikawa. 1976. Enzyme coupled immunoassay of insulin using a novel coupling reagent. J. Biochem. 79: $233-236$

Klier, G., D. Shubert, and S. Heinemann. 1977. The ultrastructural differentiation of the clonal myogenic cell line $\mathrm{L} 6$ in normal and high K + medium. Dev. Biol. 57: 440-449.

Kliman, H.J., C. Coutifaris, R.F. Feinberg, J.F. Straus III, and J.E. Haimowitz. 1989. Implantation: In vitro models utilizing human tissues. In Blastocyst implantation (ed. K. Yoshinaga|, pp. 83-91. Adams Publishing, Boston, MA.

Knoth, M. and J.F. Larsen. 1972. Ultrastructure of a human implantation site. Acta Obstet. Gynecol. Scand. 51: 385-393.

Kyte, J. and R.F. Doolittle. 1982. A simple method for displaying the hydropathic character of a protein. I. Mol. Biol. 157: 105132.

Leivo, I., A. Vaheri, R. Timple, and J. Wartiovaara. 1980. Appearance and distribution of collagens and laminin in the early mouse embryo. Dev. Biol. 76: 100-114.

Lindenberg, S., P. Hyttel, S. Lenz, and P.V. Holmes. 1986. Ultrastructure of the early human implantation in vitro. Hum. Reprod. 1: 533-538.

Lindenberg, S., K. Sundberg, S.J. Kimber, and A. Lundblad. 1988. The milk oligosaccharide, lacto-N-fucopentaose I, inhibits attachment of mouse blastocysts on endometrial monolayers. J. Reprod. Fertil. 83: 149-158.

Martin, G.R. 1980. Teratocarcinomas and mammalian embryogenesis. Science 209: 768-776.

Oshima, R.G., W.E. Howe, G.F. Klier, E.D. Adamson, and L.H. Shevinskey. 1983. Intermediate filament protein synthesis in preimplantation murine embryos. Dev. Biol. 99: 447-455.

Richardson, C.D., A. Berkovich, S. Rozenblatt, and W.J. Bellini. 1985. Use of antibodies directed against synthetic peptides for identifying cDNA clones, establishing reading frames and deducing the gene order of measles virus. I. Virol. 54: 186-193.

Ringler, G.E. and J.F. Strauss III. 1990. Recent advances in understanding the process of implantation. Curr. Opin. Cell Biol. 2: 703-708.

Rohde, L.H. and D.D. Carson. 1993. Heparin-like glycosaminoglycans participate in binding of a human trophoblastic cell line (JAR) to a human uterine epithelial cell line (RL95). J. 
Cell. Physiol. 155: 185-196.

Romagnano, L. and B. Babiartz. 1990. The role of murine cell surface galactosyltransferase in trophoblast: Laminin interactions in vitro. Dev. Biol, 141: 254-261.

Saiki, R.K., D.H. Gelfand, S. Stoftel, S.J. Scharf, R.G. Higuchi, G.T. Horn, K.B. Mullis, and H.A. Erlich. 1988. Primer-directed enzymatic amplification of DNA with a thermostable DNA polymerase. Science 239: 487-491.

Sanger, F., S. Nicklen, and A.R. Coulson. 1977. DNA sequencing with chain terminating inhibitors. Proc. Natl. Acad. Sci. 7: 5463-5467.

Sclafke, S. and A. C. Enders. 1975. Cellular basis of interaction between trophoblast and uterus at implantation. Biol. Reprod. 12: 41-65..

Shi, S.R., M.E. Key, and K.L. Kalra. 1991. Antigen retrieval in formalin-fixed, paraffin-embedded tissues: An enhancement method for immunohistochemical staining band on microwave oven heating of tissue sections. J. Histochem. Cytochem. 39: 741-748.

Stappert, J. and R. Kemler. 1993. Intracellular associations of adhesion molecules. Curr. Opin. Neurobiol. 3: 60-66.

Sutherland, A.E., P.G. Calario, and C.H. Damsky. 1988. Expression and function of cell surface extracellular matrix receptors in mouse blastocyst attachment and outgrowth. J. Cell Biol. 106: 1331-1348.

Thomas, P.S. 1980. Hybridization of denatured RNA and small DNA fragments transferred to nitrocellulose. Proc. Natl. Acad. Sci. 77: 5201-5205.

Towbin, H., T. Staehelin, and J. Gordon. 1979. Electrophoretic transfer of proteins from polyacrylamide gels to nitrocellulose sheets: Procedure and some application. Proc. Natl. Acad. Sci. 76: $4350-4354$.

Yamagata, T. and K. Yamazaki. 1991. Implanting mouse embryo stain with a LNF-I bearing fluorescent probe at their mural trophectodermal sides. Biochem. Biophys. Res. Commun. 181: 1004-1009.

Yoshinaga, K. 1988. Uterine receptivity for blastocyst implantation. Ann. N.Y. Acad. Sci. 541: 424-431. 


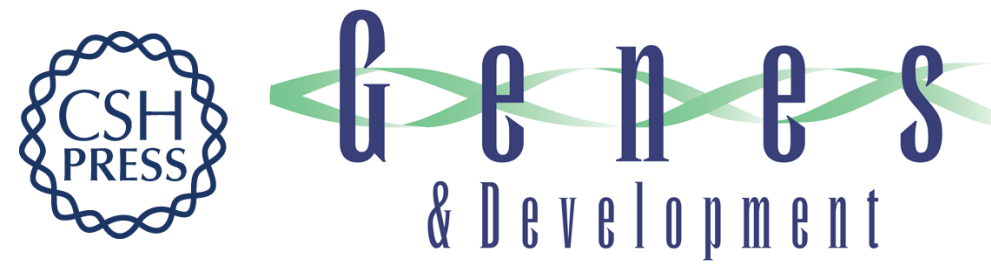

\section{Trophinin and tastin, a novel cell adhesion molecule complex with potential involvement in embryo implantation.}

M N Fukuda, T Sato, J Nakayama, et al.

Genes Dev. 1995, 9:

Access the most recent version at doi:10.1101/gad.9.10.1199

References This article cites 42 articles, 11 of which can be accessed free at:

http://genesdev.cshlp.org/content/9/10/1199.full.html\#ref-list-1

License

Email Alerting

Service

Receive free email alerts when new articles cite this article - sign up in the box at the top right corner of the article or click here.

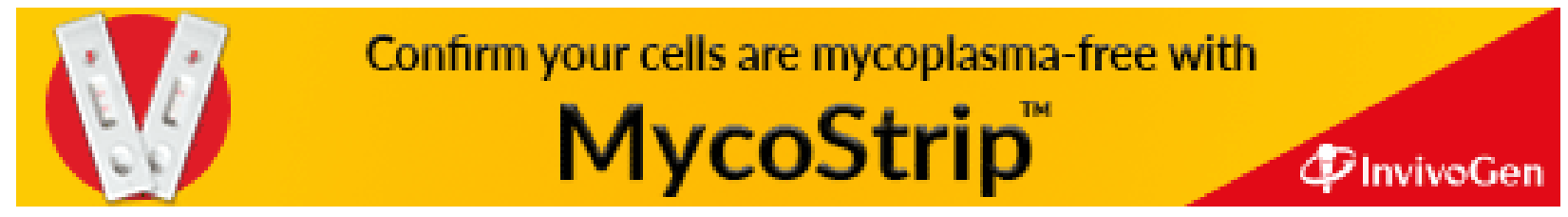

